\title{
3. To Corrupt: The ambiguity of the language of corruption in ancient Athens
}

\author{
Arlene W. Saxonhouse
}

Today the language of corruption thrives largely within the framework of moral theory. The most general sense of the term to which most scholarly attention is given seems to be the inappropriate use of public resources for private gain, with the meaning of 'public' branching out from governmental institutions to economic entities such as public corporations. The use of public resources for private gain harms the lives of those who depend on the open and fair distribution and use of public goods. Thus, the moral context enmeshes the language of corruption in a liberal world that distinguishes public from private, and the optimism of Mandeville's private vices leading to public virtues is left far behind. Instead, energies turn to completing the project of Federalist Papers No. 10 (Madison, 1987 [1788]) and developing institutions that acknowledge the ingrained pursuit of private interests but manage to 'control the effects'. Or, in a very different literature - that of communitarianism and its variants corruption may more generally refer to 'a people' (à la Machiavelli or Rousseau) who lack concern with the welfare of the whole leading to the death of the polity. Private interests draw them away from a concern with the welfare of the whole, and public corruption takes its place against public virtue. Such approaches to corruption offer valuable tools for assessing the potential of democratic regimes committed to popular welfare; however, the concept of corruption fits into other contexts where it may have meanings that are not so centrally dependent on the public/private dichotomy that lies at the heart of current discourses of corruption.

The democratic Athenians of ancient Greece had their own institution to deal with the so-called sticky hand. This was the euthunê, which required each public official to render an account before a panel of his peers before he left public office. Thucydides (like the communitarians of today) mourned the decline of popular devotion to the city as the successors of Pericles grasped at supremacy for themselves without attention to the welfare of all. Authors from ancient Athens not so enmeshed in the public/private dichotomy also understood corruption as the dissolution of an institution or practice or way of living distant from what might be seen as its 'natural' form. For Plato there was the corruption of the form - that which exists by nature and not by art or craft, and that which exists in an unchanging world of being. When brought 
into the world of daily experience and change, the form is corrupted and loses its perfection. For Thucydides, there were the perfection and imagined eternity of the Periclean city described in Pericles' funeral oration, which dissolved with Pericles' death, the pressures of war and, most importantly, the embodiment of the city in the actual lives of its citizens. From such a perspective, these authors offer a very different sense of corruption, one that takes it out of the public/ private dichotomies so prevalent today. They place the concept into a much more ambiguous but (I will suggest) richer theoretical world.

Both Plato and Thucydides offer portraits of the perfect city but then point to the necessary corruption of such cities that cannot maintain their perfection, cities that undergo transformations in a world of constant change. There is no eternity for cities; there is no city by nature. Cities are embodied - that is, built out of human beings for whom there is no eternity or perfection. In opposition to the corruption of cities, though, each author offers a new form of knowledge. This newly identified way of knowing requires the corruption of the traditional forms of literary expression. The new forms of expression that both Plato and Thucydides introduce - by transcending the corruptible forms of knowledge and politics itself-illustrate the constructive consequences of literary corruption, achieving an incorruptibility of knowledge, as they see it, which is denied to politics.

Socrates, according to the accusation of the Athenians, corrupted the youth of Athens. In Plato's dialogues, Socrates will often corrupt the texts of Homer through misquotation. Corruption of this sort can and does lead to disorder. There is no secure text of Homer to which we can refer. The youth of Athens 'corrupted' by Socrates no longer support the political agenda of the city-but such efforts 'to corrupt' may allow, even be necessary for, the emergence of the incorruptible. Thucydides' description of the civil war in Corcyra during the Peloponnesian War captures the chaos that results when language itself is corrupted and words no longer provide a stable referent. But despite the corruptibility of words with their inherent malleability, Thucydides writes a work of logoi that he claims will be 'a possession for ever' (kteis es aiei) (1982, 1.22). In doing so, he affirms the power of words to rise above the potential corruptibility that can result from the vagaries of political conflicts.

Both Plato and Thucydides understood corruption of form in a dual sense. The first is the destruction of any image of the perfection of a city. The second is the corruption of a literary genre as a necessary prelude to the eternal incorruptible forms of knowing. Both authors corrupt traditional genres within their own novel writings: Thucydides with regard to how the past is recorded and presented, Plato with his prose representations of conversations. They both engage in this corruption of literary form, though, in order to establish incorruptible forms of knowledge that will provide a political education impervious to the pressures of 
a constantly changing world that brings on events like the revolution in Corcyra. The ways of knowing in the past were subject to corruption-by the Sophists, by characters like Socrates, by those whose stories were told with prejudice and self-interest, by the dislocations of war. The new ways of knowing offered by Thucydides and Plato are intended to rise above the impermanence of the old. For Thucydides this knowledge may allow us, as he says, 'to see clearly' (1.22); for Socrates, it may allow us to 'live well'. Corruption of the old, in this fashion, gives birth to what is most valuable - and incorruptible - in life. In this sense, the ancient authors let us take corruption beyond its negative political and moral connotations in order to explore its more positive potential.

Elsewhere I have treated Socrates and the corruption of the young (Saxonhouse, 2004). In this chapter, I want to look at the writings of Plato and Thucydides as they consider how to move beyond the corruptible forms of knowledge that dominate their societies. By exploring these epistemological and genre questions, we see their relation to the political possibilities of incorruptible regimes. Ultimately, I find an ancient pessimism, which I contrast in a coda at the end of this chapter with a modern Hobbesian optimism. Hobbes's optimism, though, leads to questioning the consequences of longing for the politically incorruptible.

Any study that turns to the ancients for insights into contemporary issues must acknowledge that all the literature from that period is in some sense experimental. The literary models were few and opportunities for innovation enormous. Nevertheless, when one turns to the fifth and fourth centuries BCE, literary genres had been established and patterns of expression for offering views concerning the gods, the past, the good life and the polity in which one lived had all found their form: epic, tragedy, comedy, the expansive histories of writers like Herodotus and the now lost Hellenicus and Hecaetetus. Both Thucydides and Plato violate those forms in an effort to offer to their readers truths that exist beyond and above the corruptible knowledge that is based on the experience and discourse of their daily lives. Each believes that by consciously corrupting the literary forms of their times, he reveals a new grounding for knowledge, a knowledge that might be 'a possession forever'. The challenge that exists is whether in their effort to go beyond the corruptible knowledge offered by other literary genres these authors can offer us a politics beyond corruption. I argue that they cannot.

I am here using a very different meaning of corruption than that which dominates the current language of corruption studies. It is the language of corruption that emerges in the classical texts. Many Greek words are commonly translated by 'corruption': luô, stasis, metabolê, diaphthora. All imply the loss of some integrity, the loss of form, and suggest the process of change that such loss entails. The Greek words most commonly translated as 'corruption' are 
diaphthora and its derivative, the verbal form diaphtherein (to corrupt). The verb diaphtherein entails what we think of as 'decay from an original form' or, as in the Oxford English Dictionary definition, the loss of unity or integrity. In the Greek, as in the English, this can refer to a body, a political regime or an individual.

Let me begin with an example from The republic. Socrates has just proposed that unless philosophers become kings or kings become philosophers there will be 'no rest from ills for the cities...nor I think for humankind' (Plato, 1968, 473). His interlocutors in The republic are not as ready to accept the genuineness of this proposal as later readers of the dialogue have been. Surely, they suggest, he cannot be serious. Those who stay with the practice of philosophy, Adeimantus remarks, 'become quite queer, not to say completely vicious; while the ones who seem perfectly decent, do nevertheless suffer at least one consequence of the practice you are praising - they become useless to the cities' (487d). Socrates' response is to insist that they clarify precisely who the philosopher is:

Won't we make a sensible apology in saying that it is the nature (pephukôs) of the real lover of learning to strive for what is; and he does not tarry by each of the many things opined to be but goes forward and does not lose the keenness of his passionate love nor cease from it before he grasps the nature itself (phuseôs) of each thing. (490b)

What Adeimantus has seen and used as the basis for his evaluation of the philosopher are the result, Socrates explains, of the 'corruptions of this nature' ('tês phuseôs...tas phthoras') (490e). He has looked at how that nature, Socrates says in the next phrase, has been 'destroyed' (diollutai, dissolved) by the many. Adeimantus grounded his understanding of the philosopher in his observation of the corrupted nature of the philosopher and thus, looking at the corrupted form of the philosopher, found the philosopher a queer character, useless for cities. Studying the philosophic nature in its pure form offers a very different character, one whose benefits for the city become apparent in the later sections of the dialogue.

In elaborating his response to Adeimantus, Socrates presents numerous examples of how the philosophic nature is corrupted (diaphtheiromenous) - by the sophists, by the assemblies, by the theatre $(492 \mathrm{a}-\mathrm{b})$. At the conclusion of his examples, Socrates tells Adeimantus: 'Such is the extent and character of this destruction and corruption (diaphthora) of the best nature (phuseôs)' (495a). Socrates begins with the affirmation that there is a nature (phusis) that is the purity of the philosophic soul. The forces of the society in which the philosopher matures threaten this purity. The pressures of life in the city corrupt the natural form of the philosopher and make the young men with whom Socrates converses 
confuse philosophy with its perversions. The philosophic nature needs to be released and protected from the societal corruption if it is to retain its natural purity, just like the plants that must be nurtured on pure soil.

The world in Socrates' story has been turned upside down. The Athenians try Socrates for the corruption of their young men. Here, in The republic, Socrates tries the Athenians for the corruption of the philosopher. Each assumes that there is a pure nature that has been corrupted by the influence of the other. For the Athenians it is their youth educated according to their own laws and customs; for Socrates it is the philosophic soul. The challenge for each, as the Athenians and Socrates see it, is to preserve themselves against the destructive forces (Socrates/the Athenians) that threaten their perfection with corruption. The Athenians and Socrates each try to remove the cause of that potential corruption: the Athenians in deed by killing Socrates, Socrates in word by making philosophers kings in his Callipolis and through that exercise making the young love philosophy. Each also imagines a pristine form that experiences corruption and in each case the corruption of that form undermines the security and stability of what is perceived as the good regime, the regime worth defending.

As Socrates continues to explore who the philosopher is, he investigates what it is that the philosopher knows, as he phrases it at the end of Book V. There he says that the philosopher loves 'what is', not the many particular, embodied examples of what it is that he loves. In other words, according to Socrates, one who loves young boys will love the 'form' or 'idea' of the young boy and not attend to whether the boy has a straight or snub nose, noses such as are found in the assorted corruptions of 'the young boy' who exists in the world of daily and sensory experience. More significant than the somewhat salacious example that Socrates introduces at this point is the 'fair' or the 'beautiful' itself that resides in 'nature'. When it manifests itself for our senses to apprehend, it does so only in a corrupted particular form of a boy or a deed or a picture or whatever else we experience with our senses. The famous image of the divided line, which Socrates introduces in Book VI as he continues his search for the philosopher, clarifies further the difference between 'what is' and what, by its existence in the world of particularity, is always a corruption of form and subject to change. It is here that we learn about the famous (or infamous) 'forms', the purity of which serve, according to the language of the image of the divided line, as the beginning points from which all else is derivative or a corruption of that perfection. The highest activity of the intellect is apprehension of the incorruptible, unchanging forms. That deriving from the forms and existing in the corruptible world of change call forth only lower mental faculties such as trust or imagining. 
For Socrates, the goal of the philosopher is to attain the forms through the intellect. Otherwise, we all labour in a world of corruption, unable to divine the purity by which we can have true knowledge and by which we can evaluate the good and the bad, the beautiful and the ugly. Thus, for example, in the aporetic dialogues like the Laches or Charmides or Lysis or Euthyphro, Socrates searches for an understanding of courage or moderation or friendship or piety, definitions that are pure in their abstraction from the particular expressions in our daily activities. Thus, he rejects Euthyphro's description of acting piously by prosecuting his father as, in any sense, clarifying what piety is. Such a description does not help Socrates to understand the virtue he allegedly lacks and why the Athenians are prosecuting him for impiety. Instead, he tells Euthyphro:

I didn't bid you to teach me some one or two of the many pious things, but that eidos [form, shape] itself by which all the pious things are pious...teach me whatever this idea itself is, so that by gazing at it and using it as a pattern, I may declare that whatever is like it, among the things you or anyone else may do, is pious, and that whatever is not like it is not. (Plato, 1984a, 6d-e)

He looks for the nature (or form) of piety, the pure virtue itself, untainted by particular persons (such as Euthyphro prosecuting his father) or particular actions (such as bringing to justice a parent who allows a slave who murdered another slave to die).

But - and this is the proverbial 'big but' - in the Platonic dialogues and in Socratic discourse, we never actually find those pure forms. We do not know what piety is at the end of the Euthyphro, or what courage is after the discussion in the Laches, or what friendship is in the Lysis, though we may know what all of these virtues are not and certainly understand that the definitions we use are woefully inadequate. In the dialogues Socrates finds himself always distracted by the complex problems that arise when we search for the natural and the pure forms in the corrupt manifestations that engage us in the sensory world of what is particular and embodied. Thus, we learn from Socrates that the pure, incorruptible, unchanging forms may exist in nature, and that that nature is not readily accessible to us. Indeed, knowledge of the pure forms may be an impossible goal. Access to the purity of the philosophic nature and the purity of the forms that rise above the everyday experience of those living in a world of change is an inaccessible aspiration. We are left in the corrupt world where the changeable always marks our distance from a purified nature.

The challenge that Socrates sets forth by affirming that the unexamined life is not worth living is to educate us about the difference between what is natural, pure and uncorrupted and what is corrupted in the world in which we live, 
without ever taking us to view the uncorrupted beautiful or good itself. In The republic, he says to Glaucon, who is eager to follow him in pursuit of the forms: 'You will no longer be able to follow... although there wouldn't be any lack of eagerness on my part... Whether it is really so or not can no longer be properly insisted on. But that there is some such thing to see must be insisted on. Isn't that so?' (533a). The forms may exist, but as we live our lives we are governed by that which is far distant from them. The political world has not brought the forms down into the world in which we live - and the question that plagues The republic is whether, given the challenge of ever having access to the forms themselves, we ever could incorporate them into our cities and create the incorruptible polity.

Consider here Thrasymachus's argument in Book I of The republic - or, indeed, Glaucon's argument at the beginning of Book II. In both cases, the arguments go: we accept the laws that rule over us as if they existed by nature, as givens. Yet both Thrasymachus and Glaucon reveal that these laws or norms or rules are not in any way according to nature. Rather, they come into being as the result of agreements amongst those who are concerned with their individual welfare, not the welfare of the whole. According to Thrasymachus's phrase - that justice is the interest of the stronger - the strong are the ones who impose the laws and they do so to serve their interests. Thus, obedience to the laws serves the interests of those who made them. In Glaucon's story, the weak are the ones who fear the strong and agree to set down laws as a restraint on the strong. Here the laws serve the interest of the weak. In both accounts, though, the legal system appears as a corruption of nature, constructed against the nature of a justice that serves the welfare of all. To deviate from the laws and norms of the society in which one lives is simply to reject the corrupted system of order established by those who sought their own self-interest in setting up the laws - be they the strong as for Thrasymachus, or the weak as in Glaucon's story.

The founding of Callipolis in The republic is Socrates' effort to construct a city that is pure and uncorrupted. But the very effort to found such a pure city that looks to the welfare of the whole and not a part (especially not the rulers who would rather be philosophising than ruling) falters. Besides condemning all other regimes as corrupt, it is itself flawed, existing only through lies, tricks and massive oppression. Only in the original city-called a city of pigs by Glaucon - did we find a city according to nature (kata phusin - a phrase repeated frequently in this section of the dialogue: 369b, 370c). But who wants to live as a pig? The purity of the city of Callipolis constructed by Socrates in the middle books of The republic may exist as a form of perfection in our dreams, but as Socrates describes the forces necessary to bring such a city into being (such as getting rid of one's own wife, children and property, taking all children under ten away from their parents and sending those older than ten out into 
the fields), it is clear that we will never find this city in the corruptible world of senses, a world of change, a world of particulars, where we feel an attachment to that which is our own.

Callipolis is Socrates' effort at presenting a perfect regime free from corruption, but he fails, both in terms of the structure of the city itself with all its deceptions and perversions and in the inability to preserve the city over time. In Book VIII, we learn that even this regime created in speech cannot escape corruption. The philosophers so thoroughly trained in the mathematical arts through astronomy and harmonics find that their mathematics fails them and they miscalculate the correct timing for the mating cycle. From the unpropitious births resulting from those miscalculations come those who care more for honour than philosophy, and the form of the city is corrupted, dissolving into other regime forms, including tyranny.

Thucydides, in his turn, has his Pericles portray a version of the perfect cityhis Callipolis, so to speak - as he delivers his funeral oration for the Athenians who have died in the first year of the Peloponnesian War. Pericles speaks of the wonders of Athens, a city where

the elegance of our private establishments form a daily source of pleasure and helps to banish our cares; and the magnitude of the city draws the produce of the world into our harbour, so that to the Athenian the fruits of other counties are as familiar a luxury as those of his own. $(1982,2.38)$

The city for which the young men have died, Pericles tells his audience (and Thucydides' readers over the centuries), is 'the school of Hellas' (2.41). But Pericles not only offers praise of the city that he leads in the last third of the fifth century, he also points to its eternity in the hearts and minds of men all over the world:

For this offering of their lives made in common... [the dead] received that renown which never grows old, and for a sepulchre, not so much that in which their bones have been deposited, but that noblest of shrines wherein their glory is laid up to be eternally remembered upon every occasion on which deed or story shall call for its commemoration...and in lands far from their own, where the column with its epitaph declares it, there is enshrined in every breast a record unwritten with no tablet to preserve it, except that of the heart. (2.43)

Thus, Pericles imagines the unchanging eternity of his Athens in the incorruptible memory of future generations, in the thoughts and hearts of men rather than in the practices of everyday life. By lifting his Athens out of everyday experience, he removes it from the taint of dissolution just as Socrates attempted to do with the forms and his own Callipolis. Ultimately for Plato's Socrates, the Callipolis he 
so praises can exist only in the unseen soul, not in the practices of living beings organised into a political unit. Thucydides, though, found no such place for Pericles' Athens-except in the volume that he wrote.

Neither Pericles' Athens nor Socrates' Callipolis survives unblemished. Callipolis dissolves under the pressures of reproduction, when mathematical calculation goes awry. Pericles' city dissolves under the weight of the plague, which tells citizens (and readers) that their city does not live only in the hearts and minds of those who carry the image of the city in them. It also exists in corruptible bodies, bodies that suffer from diseases, where tongues become bloody and the breath is fetid, where pustules and ulcers surface and mar the skin, where retching prevents nourishment (2.49). There is no such 'unfelt death' as Pericles imagines in his oration (2.43). Thucydides' placement of his description of the plague in such close proximity to the funeral oration has drawn forth its share of scholarly notice, but it is worth remarking again how Thucydides' compositional technique underscores the inevitable dissolution of the images of perfection when brought into the physical existence of the city. Corruption is the corrective to the unattainable political ideal of eternity. Both Thucydides through Pericles and Plato through Socrates look for perfection in the city, and both acknowledge the inaccessibility of that perfection. Corruption inevitably occurs.

Neither author, then, allows us to escape political corruption. Yet, despite the distance at which both Plato and Thucydides put us from such political perfection, they do offer us something to replace that world of inescapable corruption in the very texts they compose and the knowledge they offer through those texts, texts that we still read millennia after the cities they wrote about disappeared (or, indeed, were never founded). But they understood that in order to give us these lasting texts, they themselves had to corrupt what had been given. Only through such corruption could they present their new ways of knowing, which offered a form of knowledge that they could not find in politics. As we all know, Plato wrote dialogues, but before him there were no dialogues except for the peculiar Melian Dialogue in the midst of Thucydides' History. The radical nature of these dialogues, so familiar to us now, easily escapes us. In offering these works - also intended as homage to his mentor, Socrates-Plato is shattering the traditional genres and modes of expression for his audience.

The dialogues are not theatre intended to be performed on stage after selection by the citizens and produced with the resources of wealthy citizens. Nor are the dialogues epics telling stories in metred verse recited by the rhapsode to an engaged audience. Often the characters will make it clear that they are characters in a revised literary form, and that they are also distorting the content of the Homeric poems. In the Apology, for example, the grand Homeric hero, the beautiful Achilles, standing firm in battle, is simply a foreshadowing of the new 
hero, Socrates. The courageous Achilles is replaced with the stooped, bug-eyed Socrates wandering through the stage of Athenian politics, rather than on the battlefields outside Troy. The vision of Homeric heroism is corrupted to serve the new interests of the Platonic dialogue. Or in Book X of The republic, Homer is dismissed because he had only 'few followers of his ways' (though all of Greece may have read/heard his poem) and his Odysseus, who had travelled widely and experienced much and expressed the desire to continue such adventures at the end of the Odyssey in Socrates' rendering, seeks the quiet life ignored by all those souls eager for fame and discovery. The leading characters of the poets are rendered useless for their original roles in Plato's writings, where they become Socratic characters rather than epic ones. The poets themselves are shown to be contradictory (see Adeimantus's speech in Book II and the whole of the Protagoras) and unreliable, worthy of little more than consistent scorn. In writing his dialogues, Plato corrupts both the forms that these poets have employed and their protagonists. In doing so, he corrupts the old ways of gaining and, most significantly, transmitting knowledge, replacing those ways with his novel dialogues.

The dialogues themselves were neither performed nor read aloud as was most of the earlier literature. Thus, they allow for the private experience we all take for granted when we read our books now. They are not public performances but are experienced by those who can read and who are drawn into conversation even when there is no one physically present with whom to speak. While our reading of the dialogues may be private, they turn us into eavesdroppers on conversations which in themselves leave us uncertain about the answers to the questions posed. The lessons learned from reading these dialogues are not precise, but rather foster the critical perspective of a Socratic questioner, the one who will not allow the traditions of a society to stand uncorrupted. With a literary form that undermines the established forms of the public recitations and the performances that tend to re-enforce (or, as with Euripides, question) the societal values of the time, Plato offers a new way to undermine those values. But in doing so - in corrupting the old forms-Plato insists that we learn the importance of the search for the incorruptible knowledge that escapes the contradictions of the changeable opinions that can wander away from us. In the Euthyphro, Euthyphro finds his beliefs walking away from him. Socrates imagines that if he had spoken as Euthyphro, Euthyphro would accuse him 'by saying that after all it's because of my kinship with him [Daedalus] that my works in speech run away and aren't willing to stay where someone sets them down' (1984a, 11c). Opinions disappear, lacking the permanence that knowledge of the incorruptible forms might offer.

As suggested above, we might never achieve knowledge of those forms and, to be sure, as the story of The republic makes clear, we cannot bring them 
uncorrupted down into the world of our daily experiences. But to be human and not a sleeping horse (as he suggests Athens is in the Apology: 30e) or a pig living in the 'natural' city of Book II of The republic requires the examined life. Examining, though, means corrupting what society offers as given and engaging others in this process, just as Socrates the corrupter of the young does. It is the dialogue form that teaches us a practice of examination that makes us aware of the inconsistencies in our beliefs and makes us long for the incorruptible forms that lie beyond that which we can find in our daily experiences. To accomplish this, the new literary form that destroys the old is essential. Only by corrupting what has been can we escape from the old forms of knowledge offered by the poets and by the strong to serve their own self-interest.

Jacob Klein (1965) writes a book that analyses in detail the Platonic dialogue entitled Meno. He prefaces this work with a study of the Platonic dialogue itself as a tool of Platonic philosophy. Drawing on the discussion of writing in the Phaedrus, Klein focuses most specifically on the playfulness of the written words - a quality that makes them 'unreliable', unable to defend or explain themselves. Thus, Klein argues, 'a written text is necessarily incomplete and cannot teach properly' (p. 11). But, consistent with the themes of the Memo, Klein continues to develop the point that words serve as 'reminders' for those who know of the forms of knowledge, though they can never capture the whole of knowledge in themselves. Instead, as Klein suggests, a 'properly written text' will initiate an intellectual movement that tries to continue the conversation begun in the text and expressed by words which in themselves are playful and variable, but which can also make us aware of a knowledge that goes beyond speech (p. 11). Klein's analysis points to the need for the dialogue as a tool that can rise above corruptible words so subject to change and manipulation - as Thucydides makes us realise in his description of the corruption of language at Corcyra (3.88) or Plato when he writes about the variability of language in democracies (8.560e-561a). The dialogue form is a necessary antidote to the potential corruption of the words out of which it is constructed. Only by being able to use the dialogue to escape the playful words that always change their meaning can we move towards a Platonic vision of incorruptible, unchanging knowledge.

Thucydides, too, confronted the challenge of finding a source of permanent knowledge given his own sensitivity to the fluidity of language and the prejudices of those who used it. Before Thucydides, Herodotus had come to dominate the practice of historia, the investigation into deeds performed and speeches spoken in the past. He reported those deeds and speeches so that the things that have been done amongst men may not be forgotten over time, and that the great and wondrous deeds performed by Greeks and by the barbarians may not be without fame, and other things and through what cause they went 
to war with one another' (I.1). To accomplish his goals, Herodotus reported the widely varying, generally charming and occasionally disturbing stories that men tell of past deeds and characters. Some of the stories (logoi) he believes; others he questions. But he is a glutton for a good tale and delights in telling a good story even if he does not believe it. Thucydides rejects all this. He will not, he tells us, write a work filled with myths. It may be less pleasurable to read his work for this reason, but because of his efforts to weigh and test the evidence and speeches of others (recognising their biases and favouritism), he will enable his readers 'to see clearly' what has occurred in the past and will occur again in the future 'according to human nature' (1.22). In this way, through his careful efforts to test the information that he gets from others, the knowledge he offers will be an unchanging 'possession for ever' (1.22). He does not compose a work for the pleasure of the moment, as (by implication) did Herodotus and those who preceded him. The truths Thucydides offers will not fade or change with the times - just as the Platonic forms remain unchanging. Though the actors may change and the circumstances will change and cities will rise and fade, though even words will change their meaning as they do during the social and political chaos at Corcyra, the knowledge gained from the study of the particular war about which Thucydides writes will enable us to know all wars, all states, all political leaders as they come into being across time and space. In Thucydides' case, the permanent truth does not come from access to the Platonic forms, but from the hard work of testing the speeches of others to distil an accurate knowledge of events and circumstances, which Thucydides then writes down in his history of the Peloponnesian War.

Thucydides' history, for the most part, follows a severe chronological order as he takes his reader successively through the almost three decades of the war. Occasionally, he deviates significantly from that order, twice specifically to recall the actions of the so-called tyrannicides, Harmodius and Aristogeiton (1.20 and 6.54). For the Athenians, these tyrannicides had become heroes of their democracy, defenders of freedom, to whom the Athenians attributed the overthrow of the Peisistratid tyranny. Twice Thucydides recalls the stories surrounding the tyrannicides and twice he affirms the inaccuracy of the tales as most people recited them. In particular, the stories told about Harmodius and Aristogeiton beautify their motives - the Athenians imagine them as acting out of a noble love of freedom. In fact, Thucydides emphatically tells his readers, they acted for petty personal interests, specifically jealousy and shame - so too with the expedition of the Greeks to Troy. It was not an oath of loyalty that brought the thousands of Greek ships to the beaches outside Troy. It was the might of Agamemnon's army (1.9). Thucydides' challenge is to demonstrate how the untested - albeit pleasing - stories that marked the histories of the past, whether presented in prose by the historians or in verse by the epic poets, offered only fallible opinions that were no more secure than (to adopt Socrates' 
simile) Daedalus's statues. The incorruptible knowledge he teaches is neither hardly so pleasant nor so easily accessible, but it is unchanging, true across time and space, and worth the effort that he has put into it and that he demands of his readers.

For Plato and Thucydides, the incorruptible cannot be found in politics, in the particular states in which they live or in the imagined polities of Callipolis or the Athens of Pericles' funeral oration. Neither of those cities of invented perfection can last. Rather, the incorruptible lies in the intellectual access to the truths to which their novel literary products lead us. There we can aspire to the permanence that eludes the political, corruptible world of constant change.

\section{Coda}

In the work of the ancient authors discussed above, we see a political pessimism. Polities are not the venue in which we can find the incorruptible. And both Socrates and Thucydides suffered at the hands of the political world. Socrates, of course, was executed and Thucydides was exiled. Plato and Thucydides offered instead a world of escape in the incorruptible knowledge towards which they directed their readers. If we jump ahead two millennia, though, and encounter the thought of Hobbes, we find a theorist who wishes to offer both truths and polities that are able to withstand the corrosive forces that brought down the cities of Thucydides and Plato. Hobbes's writings contain an optimism that polities - through the practice of an unchanging political science that abstracts from time and space - can escape what others saw as the inevitable corruption of cities. For Hobbes, the polity can become what he calls a 'mortal God' (1994 [1651], p. 109). The mortality of that God comes not from the inherent corruptibility of the physical world, as in Socrates' story of the decline of Callipolis, but from the failure to apply the science of politics fully.

Though nothing can be immortal which mortals make, yet if men had the use of reason they pretend to, their commonwealths might be secured at least from perishing by internal diseases. For by the nature of their institutions they are designed to live as long as mankind, or as the laws of nature, or as justice itself, which gives them life. Therefore, when they come to be dissolved, not by external violence but intestine disorder, the fault is not in men as they are the matter, but as they are the makers and orderers of them. (p. 210)

Barring external forces, the mortality of the regime can be addressed by the truths that Hobbes teaches - truths that will make the polity as immortal as a god. 
Hobbes devotes all of Chapter 29 of Leviathan to 'those things that weaken or tend to the dissolution of a commonwealth' (p. 10). He discusses a whole range of causes for the dissolution of commonwealths - from the belief that 'whatsoever a man does against his conscience is a sin' to the insistence on the sanctity of private property and the dividing of sovereign power to reading the books of Greeks and Romans, and so forth. But it is in the phrase that the cause lies 'not in men as they are the matter, but as they are the makers and orders of them [commonwealths]' (p. 210) that Hobbes summarises all his other points. Nothing in human nature precludes the creation of an incorruptible polity; only the science or knowledge that men use to structure those polities prevents it. With the science that Hobbes teaches we can, he assures us, turn those mortal gods into immortal ones. The challenge is to learn his simple science. As he hopefully ends the first part of Leviathan:

[W]hen I consider again, that the science of natural justice is the only science necessary for sovereigns and their principal ministers; and that they need not be charged with the sciences mathematical (as by Plato they are) further than by good laws to encourage men to the study often; and that neither Plato, nor any other philosopher hitherto, hath put into order...proved all the theorems of moral doctrine, that men may learn thereby both how to govern and how to obey; I recover some hope that, one time or other, this writing of mine may fall into the hands of a sovereign who will consider it himself (for it is short, and I think clear, ) convert this truth of speculation into the utility of practice. (pp. 243-4)

Hobbes expresses in his Leviathan the arrogance of a knowledge that can lead to regimes that will never disappear; the only challenge is to use our reason correctly in implementing that knowledge. Hobbes's legacy here to the modern world is the faith in a reason or science that rises above the corruptibility of the physical world. Plato and Thucydides, who also see knowledge as needing to rise above the corruptible world, serve as a corrective to this optimism. The incorruptible wisdom that they offer may be the knowledge that this world is constantly subject to corruption, but the truths they offer in their own writings give one the tools to understand and assess that world, to know it, but not to dream - as Hobbes did - of a permanent polity that can derive from and match the universal, unchanging truths he claims to teach. Their texts achieve immortality by contrast with the corruptible from which they try to rescue us; Hobbes's text tries to unite the knowledge he imparts with the practice of politics itself. We find in the writings of Plato and Thucydides an ancient pessimism in contrast with a modern optimism concerning the challenges of political corruption. Hobbes sees the unity between incorruptible knowledge and the polities we can build for ourselves. Plato and Thucydides are far more 
timid in their claims about the powers of any knowledge that might be 'a possession for ever (kteis es aiei)' to transform and improve the political world in which we live.

\section{References}

Hobbes, Thomas. (1994 [1651]). Leviathan. E. Curley (Ed.). Indianapolis: Hackett.

Klein, Jacob. (1965). A commentary on Plato's Meno. Chapel Hill: University of North Carolina Press.

Madison, James. (1987 [1788]). Federalist papers No. 10. In James Madison, Alexander Hamilton \& John Jay (Eds), The federalist papers. Harmondsworth: Penguin.

Plato. (1968). The republic of Plato (Allan Bloom, Trans.). New York: Basic Books. Plato. (1984a). Euthyphro (Thomas West \& Grace Starry, Trans). Four texts on Socrates (pp. 41-62). Ithaca: Cornell University Press.

Plato. (1984b). Four texts on Socrates (Thomas West \& Grace Starry, Trans). Four texts on Socrates. Ithaca: Cornell University Press.

Saxonhouse, Arlene W. (2004). Corruption and justice: the view from ancient Athens. In William C. Heffernan \& John Kleinig (Eds), Corruption: public and private (pp. 25-51). Lanham: Rowman \& Littlefield.

Thucydides. (1982). The Peloponnesian War (Richard Crawley, Trans.). New York: Modern Library. 